\section{Países Bajos, territorio reversible}

Carolina Contreras Profesora, Pontificia Universidad Católica de Chile

La experiencia de los Paises Bajos en el manejo del territorio y de las aguas es extensa. Sus habitantes poseen conocimiento acabado de sus características, interactuando dinámicamente con su hábitat. Las necesidades medioambientales y económicas, sin embargo, han obligado a replantarse e incluso revertir este complejo sistema hidráulico.

PARAísO HORIZONTAL / Los curiosos viajeros que durante el s. XVII visitaron los Países Bajos, no podían evitar sorprenderse de su planicie, llegando incluso a quejarse algunos de la monotonía que caracterizaba su paisaje (Corbin, 1994). Sin embargo, el genio con el que el pueblo holandés había domesticado la naturaleza de las aguas para ese entonces, garantizaba a estos visitantes una red de transporte claramente superior, en términos de comodidad, a la que podrían haberse encontrado en cualquiera de los países vecinos.

El poder económico alcanzado por esta nación durante el famoso siglo de oro se basó en la destreza de sus hombres para batírselas con el mar, tanto a partir de la sencilla explotación de sus recursos, como en la audaz aventura iniciada por astilleros, cartógrafos y navegantes. El aumento de la población portuaria que dicha victoria trajo consigo, debió compensarse con una importante actividad agrícola tierra adentro, lo que a su vez exigió la dominación del pantanoso territorio ubicado en torno al delta del río Rin.

El atractivo que ejercía el paisaje de Holanda para el resto de los europeos se basaba en la contemplación de un territorio fecundo a partir del esfuerzo colectivo de sus hombres. Para algunos pensadores de la Ilustración, como Voltaire, este paisaje constituía un verdadero paraíso terrenal (Corbin, 1994) producto del absoluto control y homogeneidad que ofrecía como base para una sociedad equitativa. Desde el punto de vista estético, la pintura de paisajes marítimos y agrícolas hizo su parte promoviendo el artificio y control del territorio holandés como una suerte de Arcadia donde la luminosidad del cielo proyectada sobre su extensión, de praderas o de hielo, venía a celebrar la extensión misma del mar como origen de este territorio horizontal.

Bajo el supuesto de que la administración territorial es en sí una forma de garantizar equidad, los recientes desastres producidos en varios países por oposición entre naturaleza y artificio humano, parecieran convocar tanto o más que los ideales sociales de décadas pasadas. Desde esta perspectiva, valdría la pena revisar el proyecto holandés con el fin de comprender qué lecciones aparecen en estas experiencias vinculadas a la hidráulica, para enfrentar los desafíos medioambientales del presente.

EL SISTEMÁTICO DRENAJE DEL PAISAJE HOLANDÉS / El delta de un río se define como la planicie donde éste se ramifica, produciendo múltiples desembocaduras en el mar. De encontrarse en su estado natural, un delta, además de ser un paisaje notoriamente dinámico, presentaría una multiplicidad de texturas y vegetación -y no un horizonte inmutable de agua, como muchos suelen imaginar los Países Bajos previo a la intervención humana-. Esta diversidad estaría dada en gran medida por las variaciones en los caudales de agua dulce producto de las precipitaciones anuales, el grado de afectación de estas aguas por parte de las mareas y su correspondiente salinidad, las distintas constituciones del suelo y la presencia de lagunas, dunas, pantanos y acuíferos subterráneos.

Considerando la técnica, la actitud de los primeros holandeses pareciera perseverante y testaruda, al desestimar la humedad del suelo descrito anteriormente con el fin de obtener el privilegiado acceso al mar que esta posición brinda. Sin embargo, la tecnología para producir el drenaje sistemático de la superficie que rodeaba al delta, tiene una historia de casi diez siglos, donde distintos inventos, ideologías, movimientos artísticos e intereses económicos han sido los responsables de perfilar su eficiencia y control.

\section{Low Countries, Reversible Territory}

Carolina Contreras Professor, Pontificia Universidad Católica de Chile

The Low Countries' experience with control of land and water is extensive. Its inhabitants possess comprehensive knowledge of its characteristics, dynamically interacting with their habitat. However, environmental and economic needs have required the review and even the reversal of this complex hydraulic system.

HORIZONTAL PARAIDSE / The curious travelers that during the $17^{\text {th }}$ century visited the Low Countries could not help being surprised by its flatness, with some actually complaining about the monotony that characterized the landscape (Corbin, 1994). Nevertheless, the genius with which the Dutch community had domesticated the nature of the water at that time guaranteed these visitors a clearly superior transportation system, in terms of commodity, compared to what they could have found in any other neighboring countries.

The economic power attained by this nation during the famous Golden Age was based on the dexterity of its men in fighting the sea, from the simple exploitation of its resources to the audacious adventure initiated by its shipyards, cartographers, and seafarers. The increase in port population that this victory brought with it was compensated with an important inland agricultural activity, which required domination of the swampy land located around the Rhine River delta

The attraction that the Dutch landscape held for the rest of the Europeans was based on the contemplation of a fertile land due to the collective effort of its men. For some philosophers of illustration, like Voltaire, this landscape constituted a true earthly paradise (Corbin, 1994), a product of the absolute control and homogeneity that provided a base for an equitable society. From an esthetic point of view, paintings of maritime and agricultural scenes played a role in promoting the artifice and control of Dutch land, like a sort of Arcadia, where the luminosity in the sky projected over its surface of prairies or of ice, comes to celebrate the extension of the sea like the origin of this horizontal territory.

Under the assumption that territorial administration is in and of itself a way of guaranteeing equity, the recent disasters that have occurred in various countries due to the confrontation between nature and human artifice, seem to occupy us as much as or more than the social ideals of past decades. From this point of view, it would be worthwhile to revise the Dutch project with the purpose of understanding what benefits its skilled hydraulic technology would bring us, in order to confront present environmental threats. THE SYSTEMATIC DRAINAGE OF DUTCH LANDSCAPE / The delta of a river is defined as a plain that is ramified, producing multiple outlets to the sea. In its natural state, a delta, besides offering a notoriously dynamic scene, presents multiple textures and vegetation, not an immutable horizon of water, like many tend to imagine the Netherlands to have been before human intervention. This diversity is much a product of the variance of the sweet water current, which depends of the annual precipitation, the effect on the waters due to the tides and corresponding salinity, the different constituents of the ground, and the presence of lagoons, dunes, swamps, and the underground aquifers.

From the point of view of technique, the attitude of the first Dutch appears persevering and intransigent, by downplaying the humidity of the ground described before, in order to obtain the privileged access to the sea that their location granted them. Nevertheless, the technology to produce the systematic drainage of the delta's surface has a history of almost ten centuries, where different inventions, ideologies, artistic movements and economic interests have been responsible for shaping its efficiency and control. 


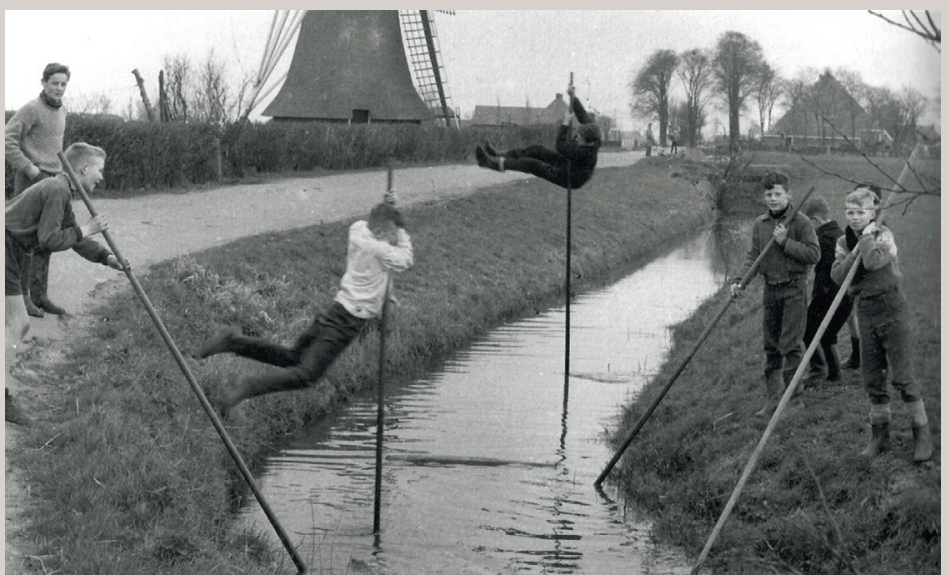

01 Interacción entre hombre y medio ambiente. Fuente: Geuze, Adriaan and Fred Feddes. Polders!: gedicht Nederland. Nai Uitgevers, Rotterdam, 2005

01 Interaction between man and environment. Source: Geuze, Adriaan and Fred Feddes. Polders!: gedicht Nederland. Nai Uitgevers, Rotterdam, 2005

Según la investigadora holandesa Fransje Hooimeijer (2008), existirían seis etapas en la colonización de este territorio: la etapa de aceptación (hasta el s. x), la etapa defensiva (s.x-s. xv), la etapa ofensiva (s. xv-s. xvII), la etapa de manipulación temprana (1800 - 1890), la etapa de manipulación $(1890$ - 1990) y la actual transición entre manipulación y adaptación.

En un principio, los terrenos más altos de la turba ubicada a orillas de los ríos fueron los lugares donde se establecieron los primeros habitantes, limpiando los terrenos de la vegetación propia de este paisaje con el doble propósito de producir combustible y disponer de un suelo cultivable. Como la limpieza del terreno se produjo desde los caminos hacia el interiory dependió de cada propietario, los frentes de estas propiedades tendieron a ser angostos, resultando en las alargadas parcelas que aún son visibles en los cultivos holandeses. Asimismo, con el fin de mantener seco este suelo ganado a la turba, se trazaron los primeros canales entre parcelas que no eran más que simples excavaciones capaces de drenar las nuevas tierras hacia los cursos naturales de agua.

Aunque la tierra extraída de estos canales se utilizó para aumentar el nivel de las parcelas, lo que no se previó fue la eventual erosión de las mismas por parte del agua transportada por los canales que, al estar conectadas a otros cursos de agua vinculados al mar, tenían niveles oscilantes inundando grandes superficies del terreno ganado. Así, en el s. x apareció uno de los primeros inventos: la represa o dam ${ }^{1}$ que, interrumpiendo un curso de agua, era capaz de prevenir la erosión y garantizar el drenaje a través de una esclusa.

Sin embargo, las variaciones climáticas exigieron instaurar prácticas todavía más ofensivas, como la construcción de diques que compartimentaran la tierra ganada y la protegieran de las crecidas del mar y los ríos. Lentamente, los sistemas de drenaje dentro de estos perímetros de dique se fueron coordinando unos con otros hasta construir un solo sistema de manejo de aguas a partir de un mosaico de patrones de tierra ganada (Reh, Steenbergen y Aten, 2007).

Lo anterior no hubiese sido factible sin la invención del molino, un sencillo artefacto hidráulico capaz de captar las diversas orientaciones del viento y transmitir esta fuerza a una rueda dotada de remos que conseguía verter un flujo de agua en otro flujo ubicado en un nivel superior. Este invento, a pesar de su perfeccionamiento a lo largo de los siglos, no lograba subir el agua a alturas mayores a un metro; ello exigió la sistematización de corridas

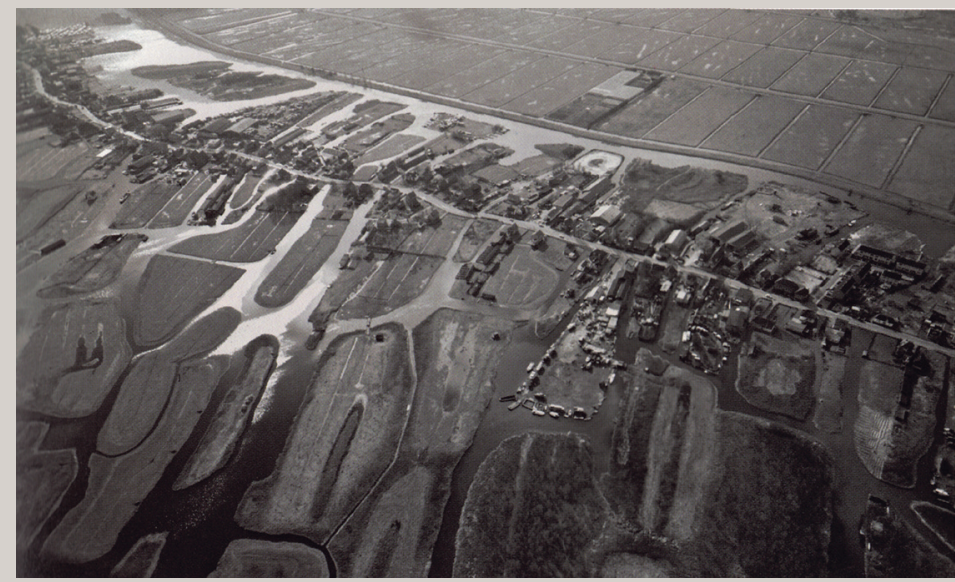

02 Asentamientos en turbas Fuente: Geuzz, Adriaan y Fred Feddes. Polders!: gedicht Nederland. Nai Uitgevers, Rótterdam, 2005 02 Settlements on turf. Source: Geuze, Adriaan and Fred Feddes. Polders!: gedicht Nederland. Nai Uitgevers, Rotterdam, 2005

According to Dutch researcher Fransje Hooimeijer (2008), there are six periods of colonization of the territory: the period of acceptance (until the $10^{\text {th }}$ century), the defensive period ( $10^{\text {th }}$ to $15^{\text {th }}$ century), the offensive period ( $15^{\text {th }}$ to $18^{\text {th }}$ century), the early manipulation period $(1800-1890)$, the manipulation period (1890-1990) and the present transition between manipulation and adaptation.

In the beginning the first inhabitants settled on the highest lands of the turf, located at the border of the rivers, razing the land from vegetation proper to the landscape, with the dual objective of producing fuel and laying out fertile land. Because the razing of land spanned from the roads to the interior and depended on each landlord, the fronts of these properties tended to be narrow, resulting in elongated parcels which are still visible in Dutch farming. At the same time, with the purpose of keeping the ground gained from the turf dry, the first canals were drawn between parcels that where no more than simple excavations capable of draining the new lands towards the natural course of the water.

Even though soil extracted from the canals was used for raising the levels of the parcels, it was not foreseen that the same soil would eventually erode, due to the water carried by the canals, which by being linked to other water flows connected to the sea, had oscillating levels, and inundated vast surfaces of gained land. This is how in the $10^{\text {th }}$ century one of first inventions surfaced, the $d a m^{1}$, which by interrupting the course of the water, was capable of preventing erosion and guaranteeing drainage through a floodgate.

Nonetheless, climatic variations required the use of more aggressive practices, like the construction of dikes that would compartmentalize the gained soil and protect it from the sea and river growths. Slowly, the drainage systems within the perimeters of the dike became coordinated with each other, until the construction of one single system of water management, all based on a mosaic of patterns of gained soil (Reh, Steenbergen y Aten, 2007).

This would not have been possible without the intervention of the windmill, a simple hydraulic artifact capable of catching various orientations of the wind and transmitting the forces to a wheel endowed with oars that achieves transferring a current of water into another current located at a higher level. This invention, despite refinement throughout the centuries, 


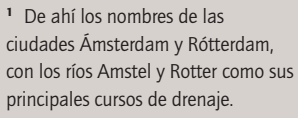

su origen de lago drenado. 3 "Un paisaje es un espacio deliberadamente fabricado para acelerar o retardar el proceso de la naturaleza. Como lo expresa Eliade representa al hombre desempeñando el papel del tiempo." (traducción de la autora)

06 a 09 Fases de implementación del proyecto para Wieringen. Oficina Palmboom \& van den Bout. Fuente: http://wwwwieringerrandmeer.nl/archief/Masterplan.pdf

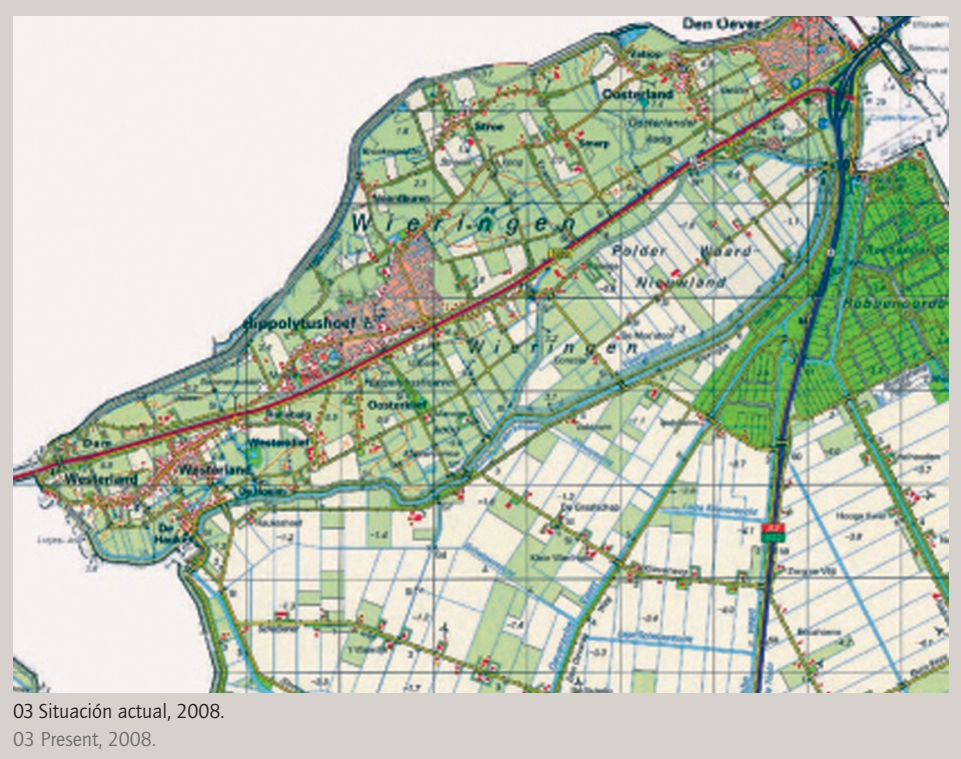

de molinos que conseguían alzar el agua hasta $4 \mathrm{~m}$, sobrepasando la altura de los diques y conduciéndola al nivel siguiente en esta secuencia de pólderes² hasta vaciarla en el mar.

Otros inventos, como el motor a vapor y luego el motor a combustible fueron haciendo cada vez más eficiente el secado de tierras, ocupando menos infraestructura y produciendo un gradual divorcio entre las disciplinas de la ingeniería hidráulica y el diseño urbano. Este sistema, de clara orientación tecnócrata, acabó por garantizar un suelo seco y plano, una verdadera tabula rasa, de la cua arquitectos y urbanistas podrían disponer para realizar las expansiones urbanas requeridas por el aumento de la población.

La estructura compartimentada de este territorio drenado dio pie en el s. xVII al establecimiento de una innovadora estrategia militar que permitió a los holandeses defenderse de las invasiones españolas. En 1629 se tomaron las primeras medidas para la construcción de una línea defensiva (Reh, Steenbergen y Aten, 2007) que tendría por misión garantizar la protección de las principales ciudades a través de una secuencia de fuertes y, entre ellos, la presencia de vastas zonas inundables. El trazado de esta línea estuvo basado tanto en la topografía natural del terreno como en la lógica de los pólderes, para luego ser subdividida en distintos planos de inundación, cada uno con su propio nivel de agua.

A fines de la década pasada, producto de importantes cambios climáticos, dicha estrategia militar recibió una nueva interpretación por parte de las autoridades medioambientales holandesas. Con el fin de producir nuevas reservas de agua dulce, como alternativa a su acelerada expulsión, se propuso el abandono de algunas estructuras de drenaje y la inundación de sus respectivos compartimentos de tierra.

Uno de los primeros proyectos de este tipo, a ejecutarse entre los años 2012 y 2032, sería el proyecto de Wieringen, diseñado recientemente por la oficina Palmboom \& van den Bout. Esta intervención consistiría en la gradual inundación de un terreno ganado al mar en el norte de Holanda; la posición estratégica de este proyecto viene a coincidir no sólo con la intención de almacenar agua, sino además con la estructuración de un corredor ecológico que conduciría la migración de algunas aves desde el interior del continente hacia el Mar del Norte. Asimismo, este terreno inundado permitiría la conexión entre dos cuerpos de agua con distintos niveles de salinidad que, desde la perspectiva ecológica, alojaría el crecimiento de una interesante vegetación halófila y desde la perspectiva del desarrollo urbano, produciría un nuevo y atractivo frente de agua.

La estructura hidráulica que hoy garantiza el drenaje de dicha superficie permitiría que en el futuro este proceso de inundación se realizara de forma gradual, evitando el desastre ecológico que una anegación repentina podría

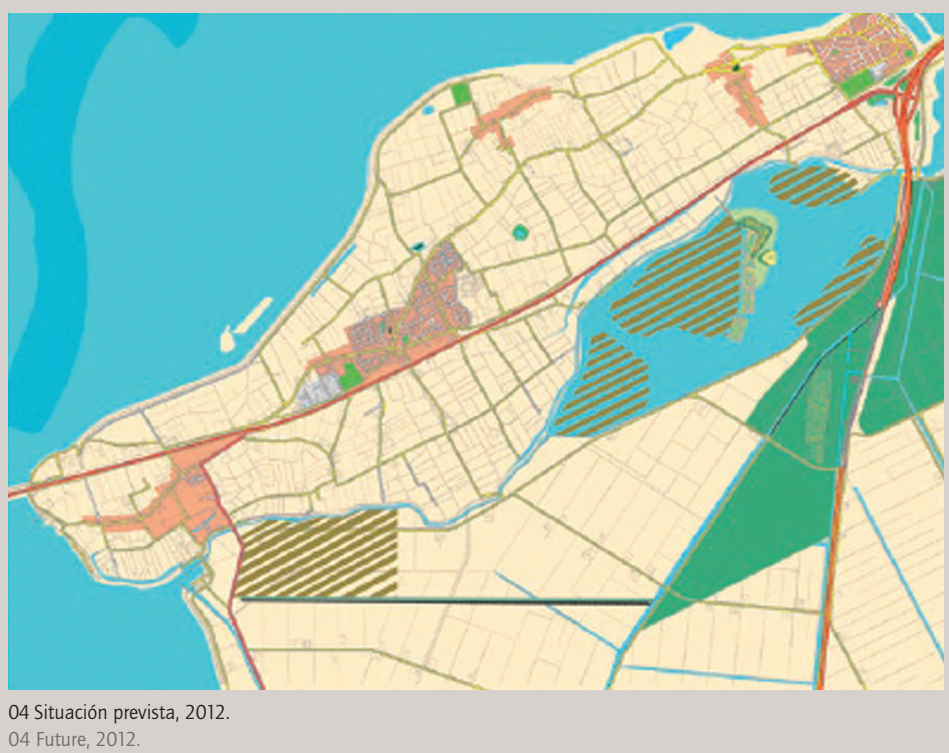

implicar y acompañando a su vez un proceso de transformación urbana flexible. La disponibilidad de suelo para estos efectos ha estado fuertemente vinculada al actual decaimiento de la actividad agrícola: la reciente incorporación de países como Polonia en la Comunidad Europea ha producido la forzosa cesión de Holanda como principal proveedor de productos lácteos del viejo continente, habilitando estos terrenos para otros usos y estimulando la generación de nuevas economías.

EL PAPEL DEL TIEMPO / "A landscape is a space deliberately created to speed up or slow down the process of nature. As Eliade expresses it, it represents man taking upon himself the role of time" ${ }^{3}$ (Jackson, 1986).

El conocimiento riguroso de la naturaleza ha permitido a los habitantes de los Países Bajos una interacción dinámica entre hombre y medio ambiente, al punto de ofrecer alternativas que permiten hoy revertir un complejo sistema hidráulico para favorecer nuevas necesidades medioambientales y económicas. En este sentido, el desempeño y versatilidad del paisaje holandés ha hecho profundamente válido el comentario de John B. Jackson con respecto al tiempo. El afinado control ejercido sobre la velocidad con la que el agua del delta es expulsada al Mar del Norte, ha permitido tanto su aceleración como su retardo, abriendo la oportunidad de hacer lento un proceso que en otros territorios parecería irreversible producto de la canalización obstinada de sus cursos de agua.

Sin embargo, el territorio holandés sigue siendo indiscutiblemente frágil. Las altas probabilidades de que en el futuro este país desaparezca bajo las aguas del Mar del Norte, debido al calentamiento global, han producido una paulatina tolerancia al agua que atraviesa varias esferas de la vida cotidiana. Desde el diseño de un conocido calzado aislante, hasta las clases obligatorias de nado, los cursos de remo y una arquitectura que explora el futuro de un país acuático, los habitantes de los Países Bajos revisan hoy el artificio de su paisaje con una humildad que parece, al menos, desafiante. ARQ

\section{Bibliografía}

Corbin, Alain y Jocelyn Phelps. "The admirable road to Scheveningen". The lure of the sea. The discovery of the seaside in the Western World 1750-1840. University of Californa Press, Berkeley, 1994. / Hoomeimeijer, Fransje. "Exploring the relationship between water management technology and urban design in Dutch polder cities". Feyen, Jan; Shannon, Kelly y Matthew Neville (ed). Water and urban development paradigms, towards an integration of engineering, design and management approaches. CRC Press, Taylor and Francis Group, Londres, 2008. / Jackson, John. Discovering the vernacular landscape. Yale University Press, New Haven, 1986. / Reh, Wouter; Steenbergen, Clemens y Diederik Aten. Sea of land: The polder as an experimental atlas of Dutch landscape architecture. Stichting Uitgeverij Noord-Holland, Wormerveer, 2007. 
1 From here derived the names of the cities Amsterdam and Rotterdam, with Amstel and Rotter rivers as principal flows of drainage.
${ }^{2}$ Polder: word of Dutch origin that makes reference to a land compartment, surrounded by its own drainage system that succeeds in maintaining parcels located in Some of the polders conserve a slightly oval shape, hinting at its origin, a drained lake.
3 "Un paisaje es un espacio deliberadamente fabricado para acelerar o retardar el proceso de la naturaleza. Como lo expresa Eliade, represento al hombre desempeñando el papel del tiempo." (traducción de la autora)

06 to 09 Phases of implementation of the project for Wieringen. Palmboom \& van den Bout office Source: http://wwwwieringerrandmeernt/archief/Masterplan pdf

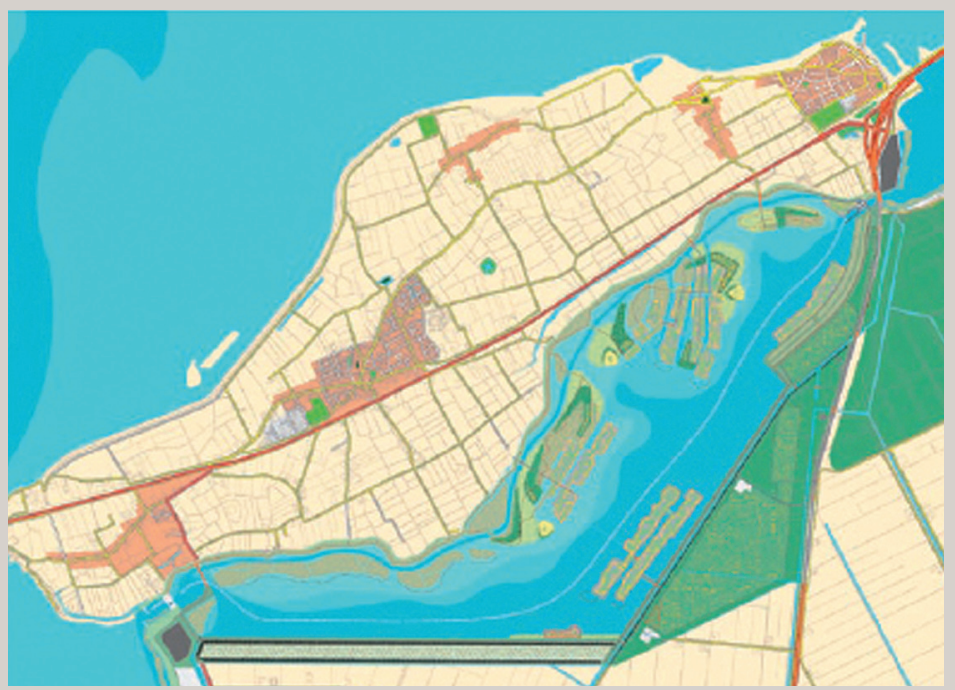

05 Situación prevista, 2017

05 Future, 2017.

didn't succeed in raising the water much more than a meter high, leading to the systemization of a line of windmills. This system raised the water four meters, higher than the dikes themselves, and carried it to the next level in a sequence of polders ${ }^{2}$, until reaching the sea.

Other inventions, like the steam motor and then the fueled motor, eventually made the drying of lands more efficient, occupying fewer infrastructures and creating a gradual divorce between hydraulic engineering and urban design disciplines. This technocratic system ended up guaranteeing a dry and flat ground, a true tabula rasa, which architects and urbanists could lay out for urban expansions required by increase in population.

In the $17^{\text {th }}$ century the compartmentalized structure of this drained land gave way to the establishment of an innovative military strategy that permitted the Dutch to defend themselves from Spanish invasions. In 1629 the first measures were taken for construction of a defensive line (Reh, Steenbergen and Aten, 2007) that as a mission would guarantee the protection of the main cities through a sequence of fortresses and, among them, the presence of vast floodable zones. The drawing of this line was based on the natural topography of the land as well as the logic of the polders, so that later they could be subdivided into different flood plains, each with its own water level.

At the end of the last decade, product of important climate changes, this military strategy received a new interpretation by the Dutch environmental authorities. With the purpose of producing new sweet water reserves as an alternative to its accelerated expulsion, the abandonment of some drainage structures and the flooding of its respective compartments of land were suggested.

One of the first of these project types, to be executed between 2012 and 2032, will be a project by Wieringen, designed recently by the offices Palmboom \& van den Bout. This intervention consists of the gradual inundation of land gained from the sea in the north of Holland. The strategic position of this project coincides not only with the intention to store water, but also with the structuring of an ecological corridor that will lead the migration of some birds from the interior of the continent towards the North Sea. Likewise, this inundated land will permit the connection between bodies of water with different levels of salinity that, from an ecological perspective, will nurture the growth of interesting halophyte vegetation, and from an urban development perspective, will provide a new and attractive waterfront.

The hydraulic structure that today guarantees drainage of aforementioned surface, will allow this flooding process to be done gradually in the future, avoiding the ecological disaster that a sudden inundation could imply, at the same time accompanying a flexible process of urban transformation. In

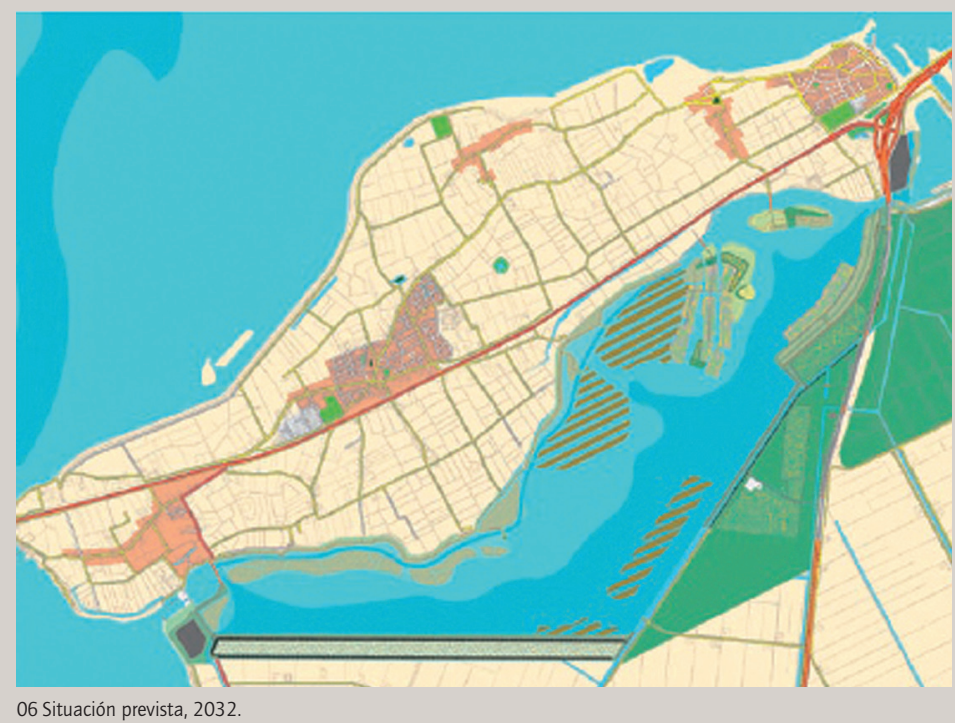

06 Situación prevista, 2032. 06 Future, 2032

this sense, it should be emphasized that the disposition of the ground for these effects has been strongly connected to the actual decay of agricultural activity. The recent incorporation of countries like Poland to the European Union has caused Holland to no longer be the principal supplier of lactic products of the old continent, habilitating these lands for other uses and stimulating the generation of new economies.

THE ROLE OF TTME / "A landscape is a space deliberately created to speed up or slow down the process of nature. As Eliade expresses it, it represents man taking upon himself the role of time" John Brinckerhoff Jackson (1986).

The rigorous knowledge of nature has permitted inhabitants of the Low Countries a dynamic interaction between man and environment, to the point of offering alternatives that allow today to reverse a complex hydraulic system with the intention of favoring new environmental and economic needs. In this sense, the work and versatility of the Dutch landscape has profoundly validated John B. Jackson's comment regarding time. The refined control exerted over the velocity with which the water of the delta is expelled to the North Sea, has permitted its acceleration as well as its retardation, yielding the opportunity to slow down a process that in other lands would have looked like the irreversible product of obstinate canalization of watercourses. Nonetheless the Dutch territory continues being inarguably fragile. The high probability that in the future this country will disappear under the North Sea waters, victimized by global warming, has produced a gradual tolerance towards the water that crosses various spheres of quotidian life. From the design of a well known water-proof shoe, to the mandatory swimming classes, the rowing classes, and architecture that explores the future of an aquatic country, the inhabitants of the Low Countries today review the artifice of their landscape with a humility that should at least seem challenging to us. ARQ

\section{Bibliography}

Corbin, Alain and Jocelyn Phelps. "The admirable road to Scheveningen". The lure of the sea. The discovery of the seaside in the Western World 1750-1840. University of Californa Press, Berkeley, 1994. / Hoomeimeijer, Fransje. "Exploring the relationship between water management technology and urban design in Dutch polder cities". Feyen, Jan; Shannon, Kelly and Matthew Neville (ed). Water and urban development paradigms, towards an integration of engineering, design and management approaches. CRC Press, Taylor and Francis Group, Londres, 2008. / Jackson, John. Discovering the vernacular landscape. Yale University Press, New Haven, 1986. / Reh, Wouter; Steenbergen, Clemens and Diederik Aten. Sea of land: The polder as an experimental atlas of Dutch landscape architecture. Stichting Uitgeverij Noord-Holland, Wormerveer, 2007. 